\title{
Pengaruh Statistik Bimbingan Orang Tua Terhadap Pendidikan Anak Di Masa Virus Covid-19
}

\author{
Ribut Suprapto', Dwi Maria Ulfa ${ }^{2}$ \\ IAI Darussalam Blokagung Banyuwangi \\ Email: ributsuprapto@iaida.ac.id ${ }^{1}$, dwimariaulfa@gmail.com²
}

\begin{abstract}
ABSTRAK
Keadaan yang sekarang sangat memprihatinkan, karena sangat berbeda dengan tahun sebelumnya, munculnya virus covid-19 ini kita harus menjaga kesehatan dan lebih berhati-hati lagi dan menjaga keluarga kita dan anak-anak, karena adanya virus ini anak-anak sangat membutuhkan bimbingan orang tua terutama Desa Tri mekar jaya kecemasan Bandar negeri suoh kabupaten lampung barat.Tujuan dari penelitian ini adalah untuk mengetahui adakah pengaruh bimbingan orang tua terhadap pendidikan anak dimasa virus covid-19 desa Tri Mekar Jaya Kecamatan Bandar Negeri Suoh Kabupaten Lampung Barat.Pendekatan dalam penelitian ini menggunakan pendekatan kuantitatif dengan analisis regresi sederhana. Populasi dalam penelitian ini adalah orang tua Desa Tri Mekar Jaya Kecamatan Bandar Negeri Suoh Kabupaten Lampung Barat, dengan sampel 30 orang tua.Untuk mengukur variabel, penelitian menggunakan kuesioner untuk keduanya.Setelah data yang terkumpul dianalisis, peneliti menemukan bimbingan orang tua $(X)$ signifikan pendidikan anak $(Y)$ desa tri mekar jaya kecamatan Bandar negeri suoh kabupaten lampung barat. Hal ini berdasarkan hasil uji signifikan regresi sederhana Fhitung= 29,629 lebih besar dari Ftabel = 3,35 sehingga menerima Ha dan menolak Ho.Kesimpulan dalam penelitian ini adalahpengaruh bimbingan orang tua terhadap pendidikan anak di masa virus covid-19 Desa Tri Mekar Jaya Kecamatan Bandar Negeri Suoh Kabupaten Lampung Barat.
\end{abstract}

Kata Kunci : Bimbingan Orang Tua Terhadap Pendidikan Anak

\begin{abstract}
The current situation is very concerning, because it is very different from the previous year, the emergence of the Covid-19 virus, we must maintain health and be more careful and take care of our families and children, because of this virus children really need parental guidance especially the village of Tri bloom triumphant anxiety Bandar Negeri Suoh West Lampung district. The purpose of this study was to determine whether there was an effect of parental guidance on children's education during the Covid-19 virus in Tri Mekar Jaya Village, Bandar Negeri Suoh District, West Lampung Regency. The approach in this study uses a quantitative approach with simple regression analysis. The population in this study were the parents of Tri Mekar Jaya Village, Bandar Negeri Suoh District, West Lampung Regency, with a sample of 30 parents. To measure variables, the study used a questionnaire for both. After the data collected was analyzed, the researcher found that parental guidance $(X)$ was significant for the education of the children $(Y)$ in the Tri Bloom Jaya Village, Bandar Negeri Suoh District, West Lampung Regency. This is based on the results of the simple regression significant test Fcount $=29.629$ is greater than Ftable $=3.35$ so that it accepts $\mathrm{Ha}$ and rejects Ho. The conclusion in this study is the effect of parental guidance on children's education during the Covid-19 virus, Tri Mekar Jaya Village, Bandar Negeri Suoh District, West Lampung Regency.
\end{abstract}

Keywords: Parental Guidance on Children's Education 


\section{A. PENDAHULUAN}

Ditengah masyarakat kita menemukan banyak anak, di hadapkan pada keadaan yang sekarang bahwa kita sebagai orang tua harus lebih memperhatikan anak-anak karena adanya virus covid-19 karena itu sangat rentan bagi siapa saja terutama anakanak,karena anak-anak sangat rentan sekali terkena penyakit.

Dan kita sebagai orang tua selalu memantau setiap saat, dan kita tidak diperbolehkan keluar rumah melainkan harus dirumah saja begitupun dengan anak-anak sekolah juga diliburkan jadi sebagai peran orang tua anak harus tetap belajar dan mengikuti kegiatankegiatan yang biasanya di lakukan di sekolah sekarang di lakukan dirumah saja jadi peran orang tua maupun guru yang hanya memantau lewat media sosial saja, kita harus menjaga anak kita agar tetap belajar dan tidak untuk bermain diluar.

Upaya kecerdasan anak mungkin dilakukan sejak dini agar anak tumbuh dan berkembang secara individu yang hebat dan cerdas baik secara intelektual,emosional,maupun spiritual, secara dini orang tua dan guru perlu memahami dan membimbing anak dengan baik dalam kondisi yang seperti ini karena adanya virus covid-19 ini kita perlu membimbing dengan baik dan sabar dalam menghadapi anak kita sendiri.

Pertumbuhan dan perkembangan ataupun kesehatan anak juga sangat penting bagi orang tua agar bisa tumbuh secara optimal.Salah satu layanan yang perlu dilakukan dalam membantu perkembangan anak tersebut ialah kegiatan bimbingan karena itu sangat membantu keseluruhan kegiatan pendidikan selain kegiatan pengajaran dan pelatihan.

Kerja sama orang tua dengan guru/pendamping merupakan salah satu kunci keberhasilan bimbingan untuk pendidikan anak usia dini,pendampingan guru yang dilakukan untuk anak orang tua juga harus selalu memantau keseharian anak masing-masing. Karena adanya kondisi yang sangat memprihatinkan maka anak wajib kita bimbing selalu. 


\section{J}

\begin{abstract}
Virus covid-19 ini telah menunjukan potensi yang positif buat kita warga Indonesia yang akan memberikan dampak luas tentang perekonomian negara yang terkena dampaknya,penyebaran virus covid19 ini sangat berdampak sistem produksi dan menggangu aktifitas sehari-hari seperti pekerja harus diliburkan dan banyak pekerja yang menggur untuk saat ini jadi perekonomian saat ini sangat berdampak bagi kita semua. Sementara pemerintah mengalami peningkatan drastis pada bahan pokok sehingga terdapat kenaikan pada barang dan harga tersebut.
\end{abstract}

Tri mekar jaya merupakan salah satu Desa di kecamatan Bandar Negeri Suoh kabupaen Lampung Barat Ibu Kota Liwa kabupaten ini di bentuk Undang-Undang nomer 6 tahun 1991 tanggal 16 agustus 1991. Kecamatan ini adalah hasil pemekaran dan kecamatan suoh yang mana kecamatan ini satu satunya di suoh. BNS (Bandar Negeri Suoh) di mekarkan pada tahun 2010 awal pemekaran ini terdiri dari 10 pekon, Yaitu Pekon Beringin Jaya, Pekon Bumi Hantatai, Pekon
Gunung Ratu,Pekon Negeri Jaya,Pekon Suoh,Pekon Tembelang,Pekon Tri Mekar Jaya,Pekon Bandar Agung,Srimulyo dan Tanjung Sari.

Dataran Desa Tri Mekar Jaya termasuk dalam dataran yang memiliki potensi sumber daya alam yang sangat baik untuk perekonomian warga sekitar. Desa Tri Mekar Jaya mayoritas masyarakat disini pekerjaannya yaitu petani karena dan pedagang dan berkembangnya desa akhirnya mulailah membangun puskesmas sendiri karena jauhnya rumah sakit dari desa ini.

\section{B. KAJIAN PUSTAKA}

\section{Bimbingan Orang Tua}

Dalam mendefisikan tentang bimbingan, Rochman Natawidjaja (1987:37) mendefinisikan bimbingan sebagai suatu proses pemberian bantuan kepada individu yang dilakukan secara berkesinambungan, supaya individu tersebut dapat memahami dirinya, sehingga dia sanggup mengarahkan dirinya dan dapat bertindak secara wajar, sesuai dengan tuntunan dan keadaan 


\section{TKaKa \\ Jurnal Komunikasi dan Konseling Islam \\ Volume I, Nomor 1, Januari 2021}

lingkungan sekolah, keluarga, masyarakat, dan kehidupan pada umumnya.

Dengan demikian dia akan dapat menikmati kebahagian hidupnya, dan dapat memberi sumbangan yang berarti kepada kehidupan masyarakat pada umumnya. Bimbingan membantu individu mencapai perkembangan diri secara optimal sebagai makhluk sosial.Yang dimaksud definisi bimbingan orang tua adalah bantuan atau pertologan yang di berikan orang tua terhadap anak-anaknya, yang di artikan yaitu bimbingan agama islam.

Materi bimbingan agama islam ialah keseimbangan antara hubungan manusia dengan Allah, hubungan manusia dengan sesama manusia, dan hubungan manusia dengan mahluk lain. Adapun materi bimbingan agama islam meliputi antara lain:

\section{a. Aqidah}

Aqidah di sebut juga iman atau kepercayaan yang merupakan titik tolak permulaan seseorang disebut muslim. Aqidah merupakan pengetahuan pokok yang disebut juga arkunal iman dan rukun iman yang terdiri atas iman kepada Allah, kepada malaikat-malaikat-Nya, kepada kitab-kitab-Nya, kepada Rasul-rasul-Nya, kepada akhir dan kepada qada' dan qadar yang tujuannya untuk meningkatkan keyakinan atau keimanan dan ketaqwaan.

\section{b. Fiqih}

Fiqih ialah pengajaran yang isinya menyampaikan materi tentang segala bentuk-bentuk hukum islam yang bersumber pada Al-Quran, Sunnah, dalil-dalil yang lain. Adapun hukum islam lima ialah: wajib, sunnah, haram, makruh, mubah.

c. Akhlak

Ajaran tentang islam ialah akhlak islam memiliki cakupan luas, sama luasnya dengan perilaku dan sikap manusia. Nabi Muhammad Saw bahkan menempatkan akhlak sebagai pokok kerasulannya. Ajaran islam secara keseluruhan mengandung nilai akhlak yang luhur, mencakup akhlak terhadap Tuhan, diri sendiri, sesame manusia dan alam sekitar.

\section{Pendidikan Anak}


Pendidikan ialah hal yang paling penting bagi manusia karena untuk menciptakan suatu kemajuan, karena tanpa adanya pendidikan mungkin tidak akan maju sampai sekarang dan tidak bisa sosialisai dengan orang sekitar, untuk memajukan suatu pendidikan di perlukan suatu landasan tertendu agar pendidikan tersebut tidak jauhdari nilai-nilai sosial.

Semakin tinggi tingkat pendidikan seseorang maka semakin tinggi pula untuk mendapatkan informasi yang lebih banyak dan medapat pengetahuan dan wawasan yang luas, tetapi jika kurangnya pendidikan maka menghambat sikap seseorang terhadap nilai-nilai yang harus dikenalkan.

Menurut Notoajmojo pendidikan dapat mengetahui seseorang, termasuk juga akan prilaku seseorang akan pola hidup terutama dalam memotivasi untuk siap berperan serta dalam pembangunan kesehatan.

\section{Tingkat Pendidikan}

1. Pendidikan Dasar (SD-SMP)

2. Pendidikan Menengah (SMA)

\section{Pendidikan Tinggi (PT)}

Dalam pendidikan ada beberapa ahli yang mengatakan tentang pendidikan. Pandangan senada dikemu-kakan Winkel bahwa pendidikan ialah bantuan yang diberikan oleh orang dewasa kepada orang yang belum dewasa agar ia mencapai kedewasaan. (Winkel 1991).

\section{Virus Covid-19}

Covid-19 merupaka singkatan dari coronavirus disease 2019 yang disebabkan oleh sindrom pernafasan akut yang parah. Virus ini terutama menyebar diantara orang-orang selama kontak dekat,sehingga melalui tetesan kecil yang dihasilakan oleh batuk,bersin, atau berbicara. Sementara tetesan ini diproduksi saat bernafas, mereka biasanya jatuh ketanah atau kepermukaan dari pada menular pada jarak jauh.

Orang juga dapat terinfeksi dengan menyentuh permukaan yang terkontaminasi dan kemudian wajah mereka.Virus ini dapat bertahan dipermukaan hingga 72 jam.Penyakit ini paling menular selama tiga hari 


\section{TKaKa

pertama setelah timbulnya gejala, meskipun penyebaran mungkin terjadi sebelum gejala muncul dan pada tahap selanjutnya penyakit.

\section{METODE PENELITIAN}

1. Pendekatan dan jenis penelitian

Menurut Sugiyono, metode penelitian kuantitatif dapat diartikan sebagai metode penelitian yang berlandasan pada filsafat positivism, digunakan untuk meneliti pada populasi atau sampel tertentu. Teknik pengambilan sampel pada umumnya dilakukan secara random, pengumpulan data menggunakan instrument penelitian, analisis data bersifat kuantitatif / statistik dengan tujuan untuk menguji hipotesis yang telah ditetapkan (Sugiyono, 2012:7).

\section{Populasi dan sampel}

Menurut Morissan, populasi adalah sebagai kumpulan atau peristiwa dimana ada teknik dengan peristiwa tersebut. Dalam penelitia ini yang dijadikan populasi adalah orang tua di desa Tri Mekar Jaya Kecamatan Bandar Negeri Suoh Kabupaten Lampung Barat.
Dilihat dari jumlah subyek yang diteliti, pengambilan sampel diperlukan karena mengingat keterbatasan waktu, tenaga, biaya, dan kemampuan yang ada sehingga tidak memungkinkan untuk meneliti seluruh subyek dalam populasi .Adapun sampel yang diambil berjumlah 30 responden dari masyarakat desa Tri Mekar Jaya Kecamatan Bandar Negeri Suoh Kabupaten Lampung Barat.

\section{Teknik pengumpulan data}

Teknik pengumpulan data dapat diartikan sebagai cara atau metode yang digunakan oleh peneliti untuk mendapatkan data dengan sebenar-benarnya yang nantinya akan sangat berguna terhadap hasil penelitian yang dilakukan. Teknik pengumpulan data dapat dilakukan dengan metode interview (wawancara), kuesioner (angket) dan observasi (pengamatan).

a. Observasi (pengamatan)

Menurut cholid narbuko dan abu achmadi, observasi (pengamatan) adalah pengumpulan data yang dilakukan dengan cara mengamati dan mencatat secara 


\section{J}

sistematik gejala-gejala yang diselidiki.(Narbuko dkk,2010:70)

Dalam hal ini, peneliti melakukan survey tempat menelitian dan meminta izin untuk melakukan penelitian sehingga mendapatkan surat keterangan telah melakukan penelitian.

b. Kuesioner (angket)

Menurut sugiyono, kuesioner merupakan teknik pengumpulan data yang dilakukan dengan cara memberi seperangkat pertanyaan atau pernyataan tertulis kepada responden untuk dijawabnya (Sugiyono,2016:197).

Dalam hal ini peneliti memberikan pernyataan dalam bentuk angket dari judul penelitian untuk mendapatkan jawaban responden (Masyarakat yang mempunyai anak usia sekolah dasar) yang telah dipilih secara acak oleh peneliti.

c. Interview (wawancara)

Wawancara adalah teknik pengumpulan data yang dilakukan dengan tatap muka secara langsung antara pewawancara dengan narasumber dimana pewawancara mengajukan sejumlah pertanyaan yang harus dijawab secara lisan oleh narasumber. Wawancara dapat dilakukan secara terstruktur maupun tidak terstruktur dan dapat dilakukan melalui tatap muka (face to face) maupun dengan menggunakan telepon (Sugiyono,2015:187)

Disini saya mendatangi seorang ibuk-ibuk dan saya sedikit bertanya-tanya tentang kondisi belajar anak mengenai belajar dirumah.

\section{HASIL PENELITIAN}

1. Uji Regresi Sederhana

a. Membuat $\mathrm{Ha}$ dan Ho dalam bentuk kalimat

Ha: Adanya Pengaruh Bimbingan Orang Tua Terhadap Pendidikan Anak Di Masa Virus Covid-19 Desa Tri Mekar Jaya Kecamatan Bandar Negeri Suoh Kabupaten Lampung Barat tahun 2020.

Ho: Tidak adanya Pengaruh Bimbingan Orang Tua Terhadap Pendidikan Anak Di Masa Virus Covid-19 Desa Tri Mekar Jaya Kecamatan Bandar 


\section{TKaKa \\ Jurnal Komunikasi dan Konseling Islam \\ Volume I, Nomor 1, Januari 2021}

Negeri Suoh Kabupaten

Lampung Barat tahun 2020.

b. Membuat $\mathrm{Ha}$ dan Ho dalam bentuk statistik

$\mathrm{Ha}: \mathrm{r} \neq 0$

Ho $: r=0$

c. Membuat tabel penolong untuk menghitung angket statistik

Tabel 4.1 Penolong Untuk Menghitung Angka Statistik

\begin{tabular}{|c|c|c|c|c|c|}
\hline \multirow{2}{*}{ No } & \multicolumn{5}{|c|}{ Tabel Penolong } \\
\cline { 2 - 6 } & $\mathrm{X}$ & $\mathrm{Y}$ & $\mathrm{X} 2$ & $\mathrm{Y} 2$ & $\mathrm{XY}$ \\
\hline 1 & 49 & 49 & 2401 & 2401 & 2401 \\
\hline 2 & 51 & 50 & 2601 & 2500 & 2550 \\
\hline 3 & 47 & 45 & 2209 & 2025 & 2115 \\
\hline 4 & 47 & 45 & 2209 & 2025 & 2115 \\
\hline 5 & 48 & 47 & 2304 & 2209 & 2256 \\
\hline 6 & 47 & 47 & 2209 & 2209 & 2209 \\
\hline 7 & 46 & 48 & 2116 & 2304 & 2208 \\
\hline 8 & 47 & 49 & 2209 & 2401 & 2303 \\
\hline 9 & 52 & 52 & 2704 & 2704 & 2704 \\
\hline 10 & 50 & 49 & 2500 & 2401 & 2450 \\
\hline 11 & 48 & 49 & 2304 & 2401 & 2352 \\
\hline 12 & 45 & 49 & 2025 & 2401 & 2205 \\
\hline 13 & 52 & 52 & 2704 & 2704 & 2704 \\
\hline 14 & 52 & 49 & 2704 & 2401 & 2548 \\
\hline 15 & 49 & 48 & 2401 & 2304 & 2352 \\
\hline 16 & 50 & 47 & 2500 & 2209 & 2350 \\
\hline 17 & 50 & 48 & 2500 & 2304 & 2400 \\
\hline 18 & 47 & 49 & 2209 & 2401 & 2303 \\
\hline 19 & 52 & 53 & 2704 & 2809 & 2756 \\
\hline 20 & 47 & 48 & 2209 & 2304 & 2256 \\
\hline 21 & 50 & 49 & 2500 & 2401 & 2450 \\
\hline 22 & 52 & 52 & 2704 & 2704 & 2704 \\
\hline 23 & 40 & 38 & 1600 & 1444 & 1520 \\
\hline 24 & 24 & 50 & 2209 & 2500 & 2350 \\
\hline 25 & 52 & 52 & 2704 & 2704 & 2704 \\
\hline
\end{tabular}

\begin{tabular}{|c|l|l|l|l|l|}
26 & 45 & 53 & 2052 & 2809 & 2385 \\
\hline 27 & 52 & 52 & 2704 & 2704 & 2704 \\
\hline 28 & 46 & 47 & 2116 & 2209 & 2162 \\
\hline 29 & 46 & 44 & 2116 & 1936 & 2024 \\
\hline 30 & 51 & 51 & 2601 & 2601 & 2601 \\
\hline Jumlah & 1457 & 1461 & 71001 & 71429 & 71141 \\
\hline \multicolumn{7}{|c|}{ Sumber: data yang telah diolah, 2020 }
\end{tabular}

a. Memasukkan Angka-angka Statistik dari Tabel Penolong dengan rumus:

1. Menghitung rumus $b$

$b=\frac{n \cdot \sum x y-\sum x \cdot \Sigma y}{n \cdot \sum x^{2}-\left(\sum x\right)^{2}}$

30.(71141)-(1457)-(1461) $30 \cdot(71001)-(1457)^{2}$

$=\frac{2134230-2128677}{2130030-2122849}=\frac{5553}{7181}=0,773$

2. Menghitung rumus a

$a=\frac{\sum y-b \sum \sum x}{n}=\frac{1461-0,773.1457}{30}$

$=\frac{1461-1126,261}{30}$

30

$=\frac{334,739}{30}=11,157$

3. Mencari jumlah kuadrat regersi $(\operatorname{Jkreg}[a])$

Jkreg $[\mathrm{a}]=\frac{\left(\sum y\right)^{2}}{n}=\frac{2134521}{30}=71150,7$

4. Mencari jumlah kuadrat regresi $(J k r e g[b / a])$

$\operatorname{Jkreg}[b / a]=b \cdot\left\{\sum x y-\frac{\left(\sum x\right) \cdot(\Sigma y)}{n}\right\}$

$=0,773.71141-\frac{(1457.1461)}{30}$

$=0,773.71141-\frac{(2128677)}{30}$

$=0,773.71141-70955.9$ 
$=0,773 \cdot 185,1$

$=143,082$

5. Mencari jumlah kuadrat residu ( $J K_{\text {Res }}$ )

$J K_{\text {Res }}=\Sigma y^{2-} J K_{\text {Reg }}\left[\frac{b}{a}\right]-J K_{\text {Reg }}[a]$

$=71429-143,082-71150,7$

$=71285,918-71150,7$

$=135,218$

6. Mencari rata-rata jumlah kuadrat regresi $\left(R J K_{\text {Reg[a] }}\right)$

$R J K_{\text {Reg }[a]}=/ K_{\text {Reg }[a]}=71150,7$

7. Mencari rata-rata jumlah kuadrat regresi $\left(R J K_{R e g[b / a]}\right)$

\section{$R J K_{R e g[b / a]}=$}

$J K_{\text {Reg }[b / a]}=143,082$

8. Mencari rata-rata jumlah

kuadrat residu $\left(R J K_{\text {Res }}\right)$

$R J K_{\text {Res }}=\frac{I K \text { Res }}{n-2}=\frac{135,218}{30-2}=\frac{135,218}{28}=$

4,829

9. Menguji signifikan

$F_{\text {hitung }}=\frac{R J K \operatorname{Reg}[b / a]}{R J K \text { res }}=\frac{143,082}{4,829}=$

29,629

Kaidah pengujian signifika:

Jika Fhitung $\geq$ F tabel, maka tolak

Ho artinya signifikan dan F hitung

$\leq \mathrm{F}$ tabel, terima Ho artinya tidak signifika. Dengan taraf signifikan $\alpha=0,01$ atau $\alpha=0,05$.
Carilah nilai $\mathrm{F}$ tabel menggunakan

Ftabel dengan rumus :

$\mathrm{F}$ tabel $=\mathrm{F}\left\{(1-\alpha)\left(d k_{\text {Reg[b/a])(dk Res }}\right\}\right.$

Ftabel $=3,35$

Ternyata Fhitung $\geq \mathrm{F}$ tabel, maka menolak Ho artinya signifikan.

10. Membuat kesimpulan

Karena Fhitung $=29,629 \geq$ Ftabel $=$

3,35 maka penolaka Ho dan Ha.

Dengan demikian terdapat

efektifitas yang signifika

bimbingan orang tua

berpengaruh terhadap

pendidikan anak di masa virus

covid-19 desa Tri Mekar Jaya

kecamatan Bandar Negeri Suoh

kabupaten Lampung Barat.

\section{E. PEMBAHASAN}

Setiap bimbingan yang disajikan kepada anak-anak dapat memberikan pengaruh bagi anak.Adanya bimbingan adalah kerangka konsep yang digambarkan oleh peneliti dalam penenlitian ini. Intensitas bimbingan yang tinggi akan membawa pengaruh bagi anakanak sehingga pendidikan lebih penting. 


\section{J}

Bimbingan orang tua mencari data tentang pendidikan belajar anak, belajar dirumah dan di sekolah bedanya apa dan bimbingan bagaimana. Bimbingan agama islam dapat dilakukan setiap hari (untuk meneliti perkembangan anak), untuk bimbingan yang lain seperti bimbingan pendidikan belajar bisa dilakukan dua hari sekali atau bahkan setiap jam belajar. Dalam penelitian ini yang diteliti adalah bimbingan orang tua dan pendidikan anak.Untuk mengukur variabel durasi bimbingan orang tua menghitung berapa hasil dengan pendidikan anak.

Salah satu pengaruh yaitu pengaruh bimbingan agama islam seperti akhlaq karena didalam bimbingan tersebut saat membelajari anak tentang prilaku atau sikap kepada orang lain, karena dilam bimbingan orang tua anak-anak sangat patuh dan cepat merspon bimbingan itu sendiri, dan bimbingan itu juga pasti punya dampak yang baik buat anak-anak.

Untuk memastikan responden bimbingan orang tua terhadap pendidikan anak di masa virus covid-19 ini, peneliti membuat pertanyaan pada kuisioner yang menyangkut belajar anak kapan waktunya bimbingan orang tua, dan yang menyatakan seberapa luas bimbingan yang di dapat oleh anak tersebut. Hubungan antara bimbingan orang tua dengan pendidikan anak termasuk penenlitian kualitatif yang bertujuan mengetahui bagaimana pengaruh bimbingan orang tua terhadap pendidikan anak di masa virus covid-19 desa Tri Mekar Jaya Kecamatan Bandar Negeri Suoh Kebupaten Lampung Barat.

Dalam penenlitian kuantitatif pengaruh antar dua variabel dapat dilihat dari uji regresi sederhana. Hasil dari uji regresi sederhana menunjukan bahwa adanya pengaruh antara variabel $\mathrm{x}$ yaitu bimbingan orang tua, terhadap variabel y yaitu pendidikan anak desa Tri Mekar Jaya Kecamatan Bandar Negeri Suoh Kabupaten Lampung Barat. Berdasarkan hasil uji regresi sederhana yang telah dilakukan kepada penelitian ini diperoleh hasil Fhitung= 29,629 lebih besar dari Ftabel = 3,35 maka menolak 


\section{J}

Ho dan menerima $\mathrm{Ha}$, artinya adanya pengaruh bimbingan orang tua terhadap pendidikan anak di masa virus covid-19 desa tri mekar jaya kecamatan bandar negeri suoh kabupaten lampung barat. Hal ini dapat dilihat juga pada tabel (X) bimbingan orang tua dan tabel (Y) pendidikan anak desa Tri Mekar Jaya Kecamatan Bandar Negeri Suoh Kabupaten Lampung Barat. Semuanya valid dan reliable.

Dengan demikian dapat diinterprestasi bahwa pengaruh bimbingan orang tua terhadap pendidikan anak di masa virus covid19 desa Tri Mekar Jaya Kecamatan Bandar Negeri Suoh Kabupaten Lampung Barat.

\section{F. KESIMPULAN}

Berdasarkan hasil penelitian dan analitis data tentang pengaruh bimbingan orang tua terhadap pendidikan anak di masa virus covis19 desa tri mekar jaya kecamatan bandar negeri suoh kabupaten lampung barat pada bab sebelumnya. Maka dari rumusan hipotesis yang telah diajukan, peneliti dapat menarik kesimpulan sebagia berikut:
Kesimpulannya, karena Fhitung $=29,629$ lebih besar dari Ftabel $=$ 3,35 maka menolak Ho dan menerima Ha. Artinya "Adanya pengaruh bimbingan orang tua terhadap pendidikan anak di masa virus covid-19 desa tri mekar jaya kecamatan bandar negeri suoh kabupaten lampung barat".

\section{DAFTAR PUSTAKA}

A, Hallen.Bimbingan dan Konseling dalam Islam. Jakarta: Ciputat Press, 2002.

Hasan Baharudun "Pendidikan Anak Dalam Keluarga Telah Epistemologis" Dalam Jurnal Vol. 3, No. 2.

Al Abrasi, Athiyah, M.1993. DasarDasar Pokok Pendidikan Islam, Jakarta : Penerbit Bulan Bintang.

Abdul Wahib, dan Mustaqim Psikologi Pendidikan, (Jakarta: PT. Rineka Cipta, 2010).

Ahmad, Tafsir, Ilmu pendidikan dalam persefektif Islam, (Bandung: Remaja Rosda Karya, 2007).

Sugiyono. 2016. Metode Penelitian Kuantitatif, kualitatif dan R\&D, Bandung : Alfabeta.

Riduwan. 2017. Pengantar Statisik, Bandung : Alfabet.

Poerwadanarminto, kamus bahasa Indonesia,(Jakarta: Balai pustaka,1993),688

Depdikbud RI, kamus, 706. 
Tamrin Nasution, Peran Orang Tua

Dalam Meningkatkan

Prestasi Belajar Anak,

(Jakarta : Gunung Mulia, 1985), 109.

Dewa Ketut Sukardi, Bimbingan dan

Prnyuluhan Belajar di Sekolah, (Surabaya: Usaha Nasional, 1993).

Dr. Syamsu Yusuf, LN, Landasan Bimbingan \& Konseling, (PT. Remaja Rosdakarya).

Singgih Gunarsa, Psikologi Perkembangan, (Jakarta : Gunung Mulia).

Awwad, Muhammad, Jaudah. 1997. Mendidik Anak Secara Islam, Jakarta : Penerbit Gema Insan Press.

Hastomo, Agung. Bimbingan Orang tua Dalam Meningkatkan Prestasi Belajar Siswa Sekolah Dasar, vol 1, no 1 (2015).

Syah, Muhibbin. Psikologi Pendidikan.Bandung : Remaja Rosdakarya, 2011

Drs. Alex Sobur, M.Si. Psikologi Umum, (CV Pustaka Setia).

Google cendikia .

https://www.kompas.com/tren/read/20 20/08/11/060500165/338.000anak-terpapar-covi.

https://scholar.google.co.id/schhp?hl =idd-19

https://id.scribd.com/document/3581 34621/Pengertian-BimbinganOrang-Tua-Dalam-MendidikAnak 


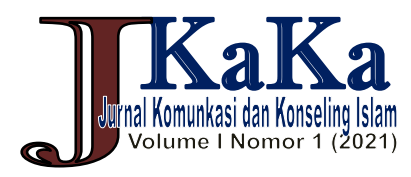

62 | Pengaruh Bimbingan Orang Tua Terhadap Pendidikananak Di Masa Virus Covid-19 Ribut Suprapto, Dwi Maria Ulfa 